\title{
The Challenges and Dynamics of Alliance Policies: Norway, NATO and the High North
}

\author{
Wrenn Yennie Lindgren \& Nina Græger
}

This chapter sets out to discuss two major framework conditions for Norwegian foreign, security and defence policy: North Atlantic Treaty Organization (NATO) and the High North. ${ }^{1}$ Having to address increasingly heterogeneous security concerns and agendas, how do alliances shape their members' foreign, security and defence policies? And how do the specific challenges related to the High North, such as Russia and other states' policy agendas, form Norwegian responses and policies? In answering these questions, we aim to explore the framework conditions in a contemporary and historical context. Apart from contributing to the literature on Norway and NATO, we endeavour to add value to the general understanding of small states' foreign and security policy enablers and constraints. ${ }^{2}$

1 The term 'High North' (nordområdene) often appears in Norwegian Government documents and is used interchangeably with 'Arctic'. It does not refer solely to Norwegian territory, but is rather a broad concept that attempts to capture developments in the wider circumpolar area. See Jonas Gahr Støre, 'The High North and the Arctic: The Norwegian Perspective', Arctic Herald, Moskva, no. 2, Jun. 2012, www.regjeringen.no/no/aktuelt/nord_arktis/id685072/.

2 Christine Ingebritsen, 'Norm Entrepreneurs: Scandinavia's Role in World Politics', in Christine Ingebritsen, Iver Neumann \& Sieglinde Gstohl (eds), Small States in International Relations, Reykjavik: University of Iceland Press, 2006, pp. 273-85; Anders Wivel, Clive Archer \& Alyson JK Bailes, 'Setting the Scene: Small States in International Security', in Clive Archer, Alyson JK Bailes \& Anders Wivel (eds), Small States and International Security: Europe and Beyond, London: Routledge, 2014, pp. 3-25. 
As a small state located at NATO's northern flank, Norway has a keen interest in keeping the High North peaceful. Norway seeks predictability and stability in its relationship with its neighbours. Its sovereignty ultimately depends, however, on the maintenance of international law and order embedded in two elements. One is the international community and particularly the United Nations, which 'is Norway's first line of defence, literally speaking. ${ }^{3}$ The other is the alliance system and especially NATO's Article 5, and Norway's close bilateral relationship with the United States. A complicating factor is, however, that Russia-West/Russia-NATO relations often are reflected in and affect Norway's bilateral relationship with Russia in the High North-for instance, the bilateral relationship soured following Russia's intervention in Georgia.

In discussing the challenges and dynamics of Norway's alliance policy, this chapter focuses on three points in particular: first, what Norway as a country does to manage its security challenges and status as a small state, both through procurement policies and multilateral security cooperation; second, how Norway manages its relationship with its High North neighbour Russia; and, finally, to what degree Norway's 2014 Arctic policy and 2006 High North strategy have been adequate responses to the challenges above. The first two points mainly concern security, notably Norway's alliance policy (NATO membership), and bilateral relations with Russia. The final point, however, seeks to outline the room Norway has for pursuing a more independent yet inclusive foreign policy in the region to promote cooperation and competence sharing.

Russia has been a returning concern in both Norwegian and Western security discourses. From being an actor of limited resources that generated nominal interest in the 15 years after the Cold War ended, Russia has clearly re-emerged as an actor on the global scene. This has been felt both in the north, where the level of Russian military activity has increased considerably, but also in the south and the east, with the Russian interventions in Georgia (2008) and especially Ukraine (2014). The current threat from the Islamic State of Iraq and Syria (ISIS) and violent extremism, however, has ostensibly created the opportunity for a rapprochement between Russia and the West in the fight

3 Ministry of Foreign Affairs, Interesser, ansvar og muligheter: Hovedlinjer $i$ norsk utenrikspolitikk (Interests, Responsibility and Possibilities: Approaches in Norwegian Foreign Policy), St. meld. 15 (2008-09), 13 Mar. 2009. 
against terrorism. This recent move revisits questions about how to engage with Russia not only for NATO, but also in a local context, namely in the High North.

Overall, the bulk of existing literature on challenges in this region has been policy-specific, covering areas such as environmental policies, minority policies, fisheries, legal issues and energy extraction, including the role of big powers such as Russia, the United States and, potentially, China. Regarding Norwegian security, the literature has focused primarily on the challenges related to military developments in Russia and Russian intentions, as well as Norway's response in the form of military presence, exercises and surveillance of the seas. This essay contributes to the debate a discussion about how Norwegian policy has developed in light of an alliance that has to deal with increasingly diversifying — and at times diverging - security concerns and agendas, while at the same time having to deal bilaterally with Russia as a great power. To do so, we hone in on Norway's changing role in the alliance, as well as the alliance's role in and influence on Norway's defence policy. The handling of two intertwined priority areas of Norwegian foreign and security policy-Russia and the High North-is studied to demonstrate Norwegian approaches towards the challenges within the respective bilateral and multilateral contexts.

The chapter begins by contextualising Norway's current global position with a brief historical account of the country's foreign and security policy. Then we give an overview of Norway's historical alliance with the United States and NATO before embarking on a discussion of Norway as a notable defence spender and contributor to international security, challenging the view that Norway is a small state. The chapter proceeds with a discussion of how Norway manages its relationship with Russia bilaterally, but with a view to global security concerns. Finally, we analyse Norway's foreign policy options in the High North, a region that encompasses Norway's number one security policy focus area.

\section{Norwegian Security and Defence Policy}

Compared to its Nordic counterparts, Norway was a latecomer in developing its armed forces and independent foreign policy. This is largely due to the fact that Norway did not gain full independence until 1905. The country was under Danish rule for nearly 400 years before it was turned over to Sweden in 1814, after Denmark's loss in 
the Napoleonic wars. Norway declared itself neutral during World War I and maintained its neutrality until it was invaded by Nazi Germany in 1940. World War II was an instigator for change in Norway's defence and security policy. In the aftermath of the war, Norway developed its armed forces in line with its place in NATO's security strategy and with national defence concerns. ${ }^{4}$

Norway's NATO membership since 1949, with the concomitant binding guarantee of mutual security in Article 5 of the treaty, reinforced the promise of support in times of crisis. The Norwegian forces were dimensioned to deny an attacker the possibility of invading Norwegian territory or, if invaded, of putting up resistance (for 48 hours) until allies could come to Norway's assistance. Back then, as today, it was understood that 'assistance would have to come from the West, and it would have to be prepared in peacetime in order to be effective in times of war'. ${ }^{5}$ Norway joined the alliance a year after turning down Sweden's 1948 proposition of a Scandinavian alliance and continues to hold that NATO defence cooperation is supreme over any other Nordic defence cooperation. ${ }^{6}$ As we shall see, however, Norway does take part in security and defence cooperation with its Nordic neighbours (Nordic Defence Cooperation, NORDEFCO).

Norway's defence policy came to be based on the understanding that external support and reinforcement were an absolute necessity. ${ }^{7}$ As an Atlantic coastal state with strong historical ties to the West, Norway has sought protection from Western great powers, in previous times particularly from the United Kingdom and, later, from the United States. ${ }^{8}$ Having a close bilateral relationship with the United States was widely recognised in Norway as providing extra reassurance of the guarantee under NATO's Article 5. In addition to NATO membership, Norwegian defence against

4 Rolf Tamnes, Norsk Utenrikspolitikks Historie, Bind 6, Oljealder 1965-1995, Oslo: University Publisher, 1997; Kjetil Skogrand, 'Allierte i Krig og Fred 1940-1970' (Allied in War and Peace 19401970), vol. 4, Norwegian Defence History, Bergen: Eide Forlag, 2004.

5 Ministry of Defence, Unified Effort, Report of Expert Commission on Norwegian Security and Defence Policy, Norwegian Government, Jun. 2015, p. 14.

6 Ståle Ulriksen, 'Balancing Act - Norwegian Security Policy, Strategy and Military Posture', Frivärld: Stockholm Free World Forum, 2013, p. 5, viewed Aug. 2016, frivarld.se/rapporter/balancingact-norwegian-security-policy-strategy-military-posture/.

7 Nina Græger, Norsk Forsvarspolitikk: Fra invasjonsforsvar til internasjonal innsats 1990-2015 (Norwegian Defence Policy: From Invasion Defence to International Projection 1990-2015), Oslo: Spartacus forlag/Scandinavian Academic Press, 2016.

8 Nina Græger \& Kristin M Haugevik, 'The Revival of Atlanticism in NATO? Changing Security Identities in Britain, Norway and Denmark', NUPI report, Oslo, 2009. 
invasion was based on universal male conscription, mobilisation and total defence, where the whole society could be activated in case of an armed attack. Throughout the Cold War period, national defence was the main objective, with any international involvement a secondary task. ${ }^{9}$

The dissolution of the Soviet Union in 1991 and the realisation that the Russians were not about to invade only gradually changed Norway's security and defence policy. Change in the structuring of the armed forces took time but Norway did manage to transition to a post-national flexible defence. ${ }^{10}$ This did not change the importance of NATO and Norway's close security relationship with the United States. But, in addition, the armed forces were transformed to meet the new international security environment and now participated in international peace operations, including peace enforcement operations. Around the year 2000, international operations were on par with national defence in Norwegian security concepts and strategies.

Preparing for an invasion over land became the main priority in postWorld War II Norwegian security and defence policy. Consequently, the army was the lead service for Norway throughout the Cold War. Regarding international deployments, the Norwegian contributions to UN missions up until 1995-especially on the Korean peninsula, in the Gaza Strip and in Lebanon-were also mainly from the army. The air force played an important role in the air missions in Bosnia, Kosovo, Afghanistan (Operation Enduring Freedom) and Libya, and the navy participated in international missions in the first Gulf War, the Gulf of Aden and the Mediterranean. The army, however, has dominated Norway's long-term international engagements, as in Lebanon, the Balkans and Afghanistan (International Security Assistance Force, ISAF). Regarding territorial defence, however, the air force and the navy have arguably become lead services. Increased Russian military activity in the High North in more recent years has made both air surveillance and maritime security a higher priority on the Norwegian security agenda, as noted by the Defence Minister in 2014: 'Our vast ocean areas, and the resources that exist

9 Nina Græger, 'Home and Away? Internationalism and Territory in the Post-1990 Norwegian Defence Discourse', Cooperation and Conflict, vol. 44, no. 1, 2011, pp. 1-18. doi. org/10.1177/0010836710396347.

10 Ministry of Defence, 'Hovedretningslinjer for Forsvarets Virksomhet og Utvikling i Tiden 1999_ 2002' (Main Guidelines for the Armed Forces' Activity and Development in 1999-2002), White Paper no. 22, Oslo: Ministry of Defence, Norwegian Government, 1998; Ministry of Defence, Kosovo-Krisen - Nasjonal rapport (Kosovo Crisis - National Report), Norwegian Government, 24 Jan. 2001. 
there, demand continuous presence and a robust capacity for surveillance, to maintain sovereignty and to exert authority. ${ }^{11}$ And, although the army remains important for territorial defence, a Russian invasion is unlikely in the foreseeable future.

\section{Norway: A Standout Defence Spender and Participator}

Many are puzzled by Norway's willingness to spend fortunes on defence material and capability contributions - in periods when most European NATO countries were and still are cutting defence budgets and investments, and despite its location in a part of the world experiencing relatively low tension. ${ }^{12}$ Norway is a big spender within defence, spending more on defence per capita than any other European country. Over the years, Norway has maintained a relatively large defence budget and number of bases and installations across the country. In view of the post-Cold War security situation and with a large, expensive defence organisation, however, Norwegian political and military decision-makers were gradually convinced of the need to reform and downsize. More importantly, Norway needed to ensure interoperability with allied forces, as international operations in practice became the main task of the armed forces in the 1990s. With the global power shift and, especially, with Russia's more forward and aggressive foreign policy, defence budgets again became a cause for concern. Norway's defence budget has been stable and predictable and now amounts to some 43 billion Norwegian kroner, a 3.4 per cent increase compared with the core military budget for $2014 .{ }^{13}$

11 Ministry of Defence, 'Sikrer Ekstra Midler i år Til Kystvakten' (Secures Extra Funds to the Coast Guard this Year), Norwegian Government, 1 Feb. 2014, viewed Aug. 2016, www.regjeringen.no/no/ aktuelt/kv-andenes-skal-repareres--sikrer-ekstra/id750283/.

12 Nina Græger, 'From "Forces for Good" to "Forces for Status"?: Small State Military StatusSeeking', in Benjamin de Carvalho \& Iver B Neumann (eds), Small State Status Seeking: Norway's Quest for International Standing, Oxon and New York: Routledge, 2015, p. 101.

13 The costs of international deployments as well as procurement investments (e.g. the F-35s) are kept outside of the annual defence budget. See Ministry of Defence, 'Government Proposes 3.4\% Defense Budget increase in 2015', Norwegian Government, 13 Oct. 2014, viewed Aug. 2016, www.regjeringen.no/en/aktuelt/Proposing-34-Defence-Budget-Increase-in-2015/id2005697/. 
In 2015, the country ranked sixth worldwide on defence spending per capita, ahead of the United Kingdom and France. ${ }^{14}$ The country's core defence budget is almost twice that of Denmark and Finland, and considerably bigger than Sweden's budget. Despite the NATO target that member states should each spend a minimum of 2 per cent of their national income or GDP on defence, few countries have been able to meet the target. At the NATO summit in Wales in September 2014, the ambitious target was replaced with the expectation that countries would halt any decline in defence expenditure. ${ }^{15}$ Norway currently spends some 1.58 per cent of GDP and, although it will not meet the 2 per cent spending target, the proposed defence plan for the period 2017-20 suggests a substantial increase in total defence expenditure. ${ }^{16}$ Given the drop in defence budgets in Europe, excluding the Baltics, Norway has put emphasis on the importance of greater self-reliance and it is expected that the defence budget will continue to be at the same level or increase. ${ }^{17}$ Recent notable procurements in the defence sector have made estimates for a growing budget more likely. As pointed out by the Chief of Defence, however, 'to further today's economic framework implies that the Armed Forces will have to be further downsized'. ${ }^{18} \mathrm{~A}$ returning issue has been Norway's propensity to spend large parts of the budget on operating expenses (e.g. maintenance), at the cost of investments in defence materials and installations or training, which strengthens the operational capability of the armed forces. Added to this is the fact that procurement costs have increased by some 4 per cent every year, which aggravates the situation. ${ }^{19}$ This challenge is not unique for Norway and also holds for several NATO countries.

14 SIPRI, 'SIPRI Military Expenditure Database', Stockholm International Peace Research Institute, 2015.

15 North Atlantic Treaty Organization, 'Wales Summit Declaration', 5 Sep. 2014, viewed Aug. 2016, www.nato.int/cps/en/natohq/official_texts_112964.htm; Denitsa Raynova \& Ian Kearns, 'The Wales Pledge Revisited: A Preliminary Analysis of 2015 Budget Decisions in NATO Member States', European Leadership Network, Feb. 2015.

16 Ministry of Defence, 'Kampkraft og bærekraft. Langtidsplan for forsvarssektoren' (Combat power and sustainability. Long term plan for the defence sector), Government Proposition $151 \mathrm{~S}$ (2015-16), Oslo: Ministry of Defence, Norwegian Government, 17 Jun. 2016.

17 SIPRI, 'Media Backgrounder: Military Spending in Europe in the Wake of the Ukraine Crisis', Stockholm International Peace Research Institute, 13 Apr. 2015.

18 The Armed Forces, Et Forsvar i Endring (A Defence Undergoing Change), Chief of Defence, 5 Oct. 2015.

19 Nils Holme, 'Forsvarspolitikken Ved et Veiskille' (Defence Policy at a Crossroad), Report, Oslo: Civita, 2013; see also, The Armed Forces, Et Forsvar i Endring, 2015. 
Norway's relatively large defence expenses compared to most of its European allies have been reasonably distributed across the three branches of its defence: navy, air force and army. Starting with Norway's sea forces, being able to surveil the vast sea areas in the High North is central in the Norwegian defence concept and thinking. ${ }^{20} \mathrm{~A}$ frigate procurement program was approved by the Norwegian Parliament in 1999 and completed over a decade later in 2011. The purchase of five Spanishmanufactured frigates was the biggest procurement expense in the history of the Norwegian navy. ${ }^{21}$ Although the navy and the coast guard have made notable advances in capabilities and acquisitions over the past 10 years, training to develop the skills for using the new, advanced technologies has been under-financed. In the Cold War era, the navy was focused largely in the coastal areas to defend the littoral areas and sea lines of communication between northern and southern Norway and was in a constant state of high readiness. While the navy remains a coastal force today, it has increased seagoing capability and is especially working to reverse the drop in capabilities experienced during the Norwegian armed forces general 'low point' from 2008-12.22 Most notably, in a series of acquisitions, a new logistics and support vessel is being made by South Korea. ${ }^{23}$ This new acquisition will allow Norway to contribute on a higher level than it has in the past as the fleet is able to provide fuel, food, fresh water, ammunition and other supplies to other vessels around the world. ${ }^{24}$

Regarding special capacities, Norway is one of the few European states with a minesweeping capacity and a leader in European mine-warfare technology. In addition to the Royal Norwegian Navy's Oksoy- and Altaclass mine warfare vessels, the fleet has HUGIN Autonomous Underwater Vehicles provided by the Norwegian defence industry (Kongsberg Maritime). Further, Norway is in the process of upgrading its submarines after it was decided that the current Ula class would likely have life

20 Ministry of Defence, 'White Paper No. 1 (2012-2013) (2013 Budget)', presented to the Norwegian Parliament, 14 Sep. 2012.

21 Ministry of Defence, 'Future Acquisitions for the Norwegian Armed Forces 2014-2022', Norwegian Government, Mar. 2014, viewed Aug. 2016, www.regjeringen.no/globalassets/upload/fd/ temadokumenter/acquisitions-2014-2022_mars-2014.pdf.

22 Ulriksen, 'Balancing Act - Norwegian Security Policy, Strategy and Military Posture', 2013.

23 Ministry of Foreign Affairs, 'Largest Ship of the Norwegian Navy Under Construction in South Korea', Norway: The Official Site in South Korea, 25 Jun. 2015, viewed Aug. 2016, www.navyrecognition. $\mathrm{com} /$ index.php/news/defence-news/year-2013-news/august-2013-navy-world-naval-forces-maritimeindustry-technology-news/1191-south-koreas-dsme-wins-contract-for-design-and-build-of-a-newlogistics-support-vessel-for-norway.html.

24 Interview with employee in the Norwegian Navy, May 2015. 
extensions until 2020 and then be replaced. ${ }^{25}$ These submarines are viewed as a strategic deterrent by the Ministry of Defence ${ }^{26}$ and are esteemed by experts to be Norway's strongest deterrent against military threats at sea. ${ }^{27}$ The ongoing planning of the procurement of new submarines has reportedly involved discussion of possible joint scenarios with NATO partners Poland and the Netherlands, who are also in the process of planning their future procurements, ${ }^{28}$ thus illustrating the international dimension of Norwegian procurement policy.

In addition to easing national concerns, these capacities enable Norway to participate actively in a multilateral context, also beyond NATO. Maritime surveillance and anti-piracy activities are two areas of particular Norwegian interest and involvement. Norway has participated in the European Union Naval Force-Operation Atalanta (EU NAVFOR), and in NATO's Operation Ocean Shield with vessels in the Gulf of Aden since 2008. Norway was also the first nation outside of Asia to join ReCAAPthe Regional Cooperation Agreement on Combating Piracy and Armed Robbery Against Ships in Asia, which works to fight pirates and other armed attacks against shipping in the Asian region, an important arena for Norwegian trade. It is also the only non-EU member of the Maritime Surveillance project (MARSUR), which was launched by the European Defence Agency in 2005 to create a network using existing naval and maritime information exchange systems.

Significant upgrades are also taking place in the Norwegian air force. The role of the Norwegian fighter plane fleet in the surveillance of the vast sea areas around Norway as well as responding to increased Russian air activity in the High North is essential. ${ }^{29}$ The principle decision to replace the country's 52 F-16 fighter planes with 57 F-35 aircraft was approved by parliament in 2008, with the first training planes expected to be ready in 2017 and the remaining planes by 2020. As with the F-16s, the Norwegian Government opted for the US planes, to be manufactured by Lockheed Martin. In justifying the purchase, the government emphasised the excellence of the F-35s-as with the frigates before that-in surveillance

25 Ministry of Defence, 'Future Acquisitions for the Norwegian Armed Forces, 2014-2022', 2016.

26 Ministry of Defence, 'A Defence for Our Time', Government Proposition no. 73 (2011-12), presented to the Norwegian Parliament, 23 Mar. 2012.

27 Interview with employee in the Norwegian Navy, May 2015.

28 'Norway May Go Dutch with Poland on Subs', Defence Industry Daily, 10 Sep. 2015, viewed

Aug. 2016, www.defenceindustrydaily.com/ula-tech-norways-next-submarine-fleet-07609.

29 Ministry of Defence, Unified Effort, 2015, p. 21. 
and demonstration of sovereignty in the High North, as well as in combat (e.g. stealth capabilities) in international operations. ${ }^{30}$ Apart from these qualities and the political prestige attached to the acquisition itself, these purchases signal to allies and partners that Norway is a country that takes responsibility for its own security, both nationally and globally. ${ }^{31}$ Buying from American manufacturers also contributes to maintaining the close political bilateral relationship. In the 2017-2020 Long Term Defence Plan, the Chief of Defence emphasised national defence concerns and capacities aimed at protecting sovereignty, with the air force playing a central role. ${ }^{32}$

As a lead service during the Cold War, the Norwegian army was a priority in defence budgets. The army took the main cuts when the defence structure was downsized in the late 1990s and early 2000s and its main activity became, to a large extent, to be a provider of personnel to international operations. During 2003-14, the ISAF mission was its primary focus, as well as some other smaller operations. Defence spending related to the Norwegian army has mainly been directed towards lighter equipment, training and exercises, and operating expenses rather than procurement programs. The more forward-leaning Russian foreign policy posture is expected to upgrade the role of the army also in a national context. The proposed increased army presence in the two northern counties is, however, mainly a reallocation (omdisponering) of existing forces, not an increase in the total volume of army forces. ${ }^{33}$

\section{Interoperability with NATO: The Role of Exercises}

Close allies talk to and inform one another and work together, and are preferred partners. Participating in procurement programs, such as the Joint Strike Fighter program, connects Norway to NATO's most powerful member, both politically and militarily. Participating in the F-35 procurement program and the earlier F-16 program confirms-at least in Norway-the close and essential relationship with the United

30 Græger, 'Home and Away?', 2011.

31 Græger, 'Home and Away?', 2011.

32 This prediction is based on Fagmilitært råd (FMR), whose proposals are expected to be an essential input into the next defence plan.

33 The Armed Forces, Et Forsvar i Endring, 2015, p. 38ff. 
States. Norwegian policy avers that it cannot take American interest for granted, and thus needs to work to keep the United States interested in the defence of Norway, also through force contributions-a policy that has not always been problem free. ${ }^{34}$ According to the Norwegian Government, a strong transatlantic relationship is 'important not only for Norwegian security, but for the security of the entire Euro-Atlantic area and for global stability'. ${ }^{35}$ In order to have this kind of partnership, forces need to be interoperable. Hence, Norwegian procurement policies and exercises are closely linked together.

Norway puts heavy emphasis on NATO joint exercises, especially on Norwegian soil, claiming that they ensure that NATO structures and forces are familiar with the Norwegian context (e.g. climate and terrain), interoperable and that the alliance's military capability is maintained and strengthened. Norway will be hosting a major NATO exercise in 2018, which the Defence Minister sees as 'Good [Gledelig] news for Norway and important for the Armed Forces'. ${ }^{36}$ Procurement policies are also important for Norway's participation in NATO exercises beyond Norwegian territory. For instance, in summer 2014, Norway's Aegis frigate participated in the world's largest maritime exercise 'Rim of the Pacific', or RIMPAC, off Hawaii. Despite the existence of the exercise since the early 1970s, as Norway's first time participating, it was considered to have considerable strategic significance for the Norwegian defence community.

In June 2015, Norway participated in the annual, US-led Baltic Operations (BALTOPS) exercise, aimed at strengthening interoperability, capabilities and maintaining regional security. The exercise involved scores of ships and aircraft from 17 countries conducting naval drills in the Baltic Sea. Fourteen NATO allies were joined by NATO partners Finland, Georgia and Sweden, with 5,600 troops involved. ${ }^{37}$ In January that year, Norwegian forces were among the 25,000 allied forces exercising together in a high-visibility exercise on the Iberian Peninsula that focused on crisis management. Furthermore, the North Atlantic

34 Græger, 'Home and Away?', 2011, p. 100.

35 Ine Eriksen Søreide, 'Speech at RIMPAC 2014 Seminar in Oslo May 12 2014', Minister of Defence, Ministry of Defence, 12 May 2014, viewed Aug. 2016, www.regjeringen.no/en/aktuelt/ Speech-at-RIMPAC-2014-Seminar-in-Oslo-May-12-2014/id759104/.

36 Ministry of Defence, 'NATO Sier 'Ja' Til Stor-øvelse i Norge i 2018' (NATO Says 'Yes' to Major Exercise in Norway), Press Briefing no. 9/2015, Norwegian Government, 4 Feb. 2015.

37 Participants include Belgium, Canada, Denmark, Estonia, Finland, France, Germany, Georgia, Latvia, Lithuania, the Netherlands, Norway, Poland, Sweden, Turkey, the United Kingdom and the United States. 
Council accepted Norway's offer to host the high visibility exercise in 2018, which, consistent with Norway's long-term efforts, will focus on collective defence. In her speech 'One for All, All for One', which refers to the security guarantee in Article 5, Defence Minister Ine Eriksen Søreide put a particular emphasis on the importance of collective self-defence for Norway and linked such exercises back to Norway's core concept. ${ }^{38}$ Exercises are a reinforcement of Norway's alliance policy and close bilateral relationship with the United States. While welcoming the opportunity to raise the alliance's awareness of the north, however, Minister Søreide made the caveat that it was important to note that the exercise will benefit all allied and partner nations. ${ }^{39}$

\section{The Norwegian Agenda in NATO}

With regard to NATO, the Norwegian security and defence discourse is marked by a high degree of continuity. The defence of Norway is anchored in NATO's Article 5 and the close bilateral relationship with the United States, as noted above.

Norway has been an active member of NATO and has contributed to NATO activities and operations to maintain the mutual security guarantee and to ensure that the allies are likely to come to Norway's assistance in the event of an armed attack. To that end, the United States has prestocked military materials in Norway for quick access in times of crisis. ${ }^{40}$ Furthermore, NATO's Joint Warfare Centre is located on the west coast in Stavanger, and has survived the many cuts of NATO presence (bases, installations) during the 1990s and 2000s. If, however, Norway was to find itself in a situation where NATO for some reason will not or cannot engage militarily, capable, modern and flexible Norwegian armed forces are necessary. This argument was key when seeking domestic support from the general public and the military for the transformation of the armed forces from a static territorial defence into a more flexible tool, both. ${ }^{41}$

38 Ine Eriksen Søreide, 'Speech by Ine Eriksen Søreide: “One for All, All for One”, Minister of Defence, Norwegian Government, 18 Mar. 2015, viewed Aug. 2016, www.regjeringen.no/en/ aktuelt/speech-by-ine-eriksen-soreide-one-for-all-all-for-one/id2401315/.

39 Søreide, 'Speech by Ine Eriksen Søreide: “One for All, All for One”, 2015.

40 Preparedness in the event of an attack on Norway or other allies is also a NATO concern. According to the 2015 Expert Commission's report: 'NATO is in the process of clarifying command and control relations between NATO and national command structures in the event of crisis and war' (Ministry of Defence, Unified Effort, 2015, pp. 40-41).

41 Græger, 'Home and Away?', 2011, p. 100. 
Being able to offer relevant and capable forces is also important to fulfil Norway's role and commitments as a NATO member. In terms of military assets, for a small country, Norway pulls above its weight. Through its procurement policy and deployments to international operations, Norway has also sought influence, status and recognition in NATO and other important fora, and vis-à-vis central allies, a strategy that has been referred to as a 'troops-for-influence' policy ${ }^{42}$ and a 'forces-for-status' policy. ${ }^{43}$ All of these practices may accord Norway a special status with the United States, which potentially enhances Norway's status inside NATO as well as its security, as Nina Græger points out. ${ }^{44}$ In addition to contributing beyond the expectations of a state of its size, this also enables Norway to follow the moves of its neighbour closely, in the interest of both domestic and international security. This puts into question the extent to which this relatively high defence spending also enables a more independent direction in its foreign policy, and in the region, as we shall see below.

Regarding NATO policies, the primary input from Norway in the most recent strategic concept process was the 'Core Area Initiative', a 'non-paper' issued in 2008. The need to establish a better balance between NATO's engagement at home and abroad was a-if not the-major concern in Norway's views on and input into the strategic concept revision process during 2008-10. ${ }^{45}$ Norway was not alone in expressing concerns about powerful neighbours and putting forward a call for the need to review NATO's strategy in light of the new developments, which were supported by the Eastern European members. The main message of the Norwegian initiative was that NATO should focus on and direct its training and exercises more towards its core tasks (e.g. Article 5) and the challenges in its neighbourhood to balance the out-of-area operations that had become NATO's main priority since the mid-1990s. ${ }^{46}$ Regarding national defence responses, the concerns about Russian foreign policy were reflected in the concept of 'threshold (or literally "doorstep") defence'. ${ }^{47}$

\footnotetext{
42 Nina Græger, 'Norway and the EU Security and Defence Dimension: A “Troops-for-Influence” Strategy', in Nina Græger, H Larsen \& H Ojanen, The EDSP and the Nordic Countries: Four Variations on a Theme, Programme on the Northern Dimension of the CFSP, Helsinki \& Berlin: Ulkopoliittinen instituutti \& Institut für Europäische Politik, 2002, pp. 33-89.

43 Græger, 'Home and Away?', 2011, pp. 91-92.

44 Græger, 'Home and Away?', 2011, p. 100.

45 Jakub Godzimirski, Nina Græger \& Kristin M Haugevik, Towards a NATO à la Carte? Assessing the Alliance's Adaptation to New Tasks and Changing Relationships, NUPI Report, 2010.

46 Græger, 'Home and Away?', 2011, p. 15.

47 Ministry of Defence, 'White Paper No. 1'; Ministry of Defence, 'A Defence for Our Time', 2012.
} 
NATO's response to the Ukraine crisis evolving in 2014 demonstrates that the majority of NATO countries now support a rebalancing between deterrence and international operations. NATO's Readiness Action Plan - which is 'the biggest reinforcement of NATO's collective defence since the end of the Cold War', according to NATO secretary general Jens Stoltenberg-was unveiled at the 2014 NATO summit in Wales. ${ }^{48}$ The plan is composed of two pillars: immediate 'assurance measures' and longer-term 'adaptation measures'. Assurance measures focus on increased activity for assurance and deterrence and involve immediate reinforcements of alliance presence in the eastern part of the alliance to increase readiness in the area. Adaptation measures, which are still under implementation, involve longer-term changes to the alliance's force posture and its capabilities to respond more quickly to emergencies. ${ }^{49}$ As part of the assurance measures, Norway (along with Belgium, Italy and the United Kingdom) assumed responsibility for airpolicing duties as of 1 May 2015. Norway is also part of the UK-led Framework Nation Concept (FNC) initiative-a Joint Expeditionary Force (JEF) that also includes the Netherlands, Denmark, Estonia, Latvia and Lithuania. The JEF is set to deploy rapidly into theatre, particularly in the Baltic region, to conduct the full spectrum of operations, and to increase alliance readiness and ability to project maritime and amphibious power in the North and Baltic Seas..$^{50}$ Regarding its timeline, the United Kingdom intends to integrate JEF partners' contributions fully into the UK's existing high-readiness capabilities before $2018 .{ }^{51}$ In the Norwegian view, the JEF and other initiatives within the Readiness Action Plan, as well as later decisions and follow-up measures at the Warsaw NATO Summit in July 2016, build on the same ideas that were forwarded in the 2008 Core Area Initiative, namely that the alliance should put its emphasis on its periphery over out-of-area operations.

The Alliance's strategic shift of focus to the Baltic Sea region and eastern NATO members, which occurred from northern fall 2014 to northern spring 2015, has been described by various scholars as a 'new normal'

48 NATO, 'NATO's Readiness Action Plan: Factsheet', Dec. 2014, p. 1.

49 NATO, 'NATO's Readiness Action Plan: Factsheet', May 2015, p.1.

50 Xavier Pintat, 'NATO's Readiness Action Plan: Assurance and Deterrence for the Post-2014 Security Environment', Sub-committee on Future Security and Defence Capabilities, NATO Parliamentary Assembly, 21 Aug. 2015, pp. 7-8.

51 Pintat, 'NATO’s Readiness Action Plan', 2015. 
for cooperative security. ${ }^{52}$ Despite their non-NATO status, both Sweden and Finland have stepped up cooperation with alliance members, on multilateral and bilateral levels, intensifying debates about full membership. ${ }^{53}$ Impetus for this shift and the development of the 'new normal' contextualisation came in the form of repeated Russian military activity in the Baltic Sea region, where Russian air activity-including heavy strategic bombers-tripled during 2013-14. ${ }^{54}$ The activity also includes incursions into Nordic and Baltic air space and the newsworthy, intensive submarine incident in Sweden in October 2014.55 Finnish and Swedish NATO membership debates also intensified when Russia conducted a big military exercise where the scenario allegedly was a rapid intervention in the islands of Alland (Finland), Gotland (Sweden), Bornholm (Denmark) and northern Norway. ${ }^{56}$

\section{Norway, Russia and the 'Dual Policy' Tradition}

As mentioned in this chapter's introduction, Norway-NATO relations and Norway-High North issues are somewhat inseparable. Due to geography, Norway-High North issues naturally involve Norway's bilateral relations with Russia. In addition, as Nina Græger argues: 'A complicating element is that this relation is not only defined by bilateral relations but also mirrors the temperature in the relationship between Russia and the West. ${ }^{57}$ Tuomas Forsberg and Græme Herd (2015) suggest

52 Anna Wieslander, 'A New Normal for NATO and Baltic Sea Security', UI Brief, no. 2, 2015; Søreide, 'Speech by Ine Eriksen Søreide: “One for All, All for One”, 2015.

53 See for instance Erik Brattberg \& Henrik Breitenbauch, 'Time for Sweden to Join NATO', The American Interest, 25 Jun. 2015. For discussion on Swedish and Finnish policy towards and engagement in NATO, see Hannah Ojanen, 'Finland's Relation with NATO in the Shadow of Russia', Cicero Foundation Commentary no. 14/03, Sep. 2014.

54 The Armed Forces, Et Forsvar i Endring, 2015, p. 15.

55 Aylin Matlé \& Alessandro Scheffler Corvaja, 'From Wales to Warsaw: A New Normal for NATO?', Fact and Findings: Prospects for German Foreign Policy, no. 187, Oct. 2015; as also picked up in Ministry of Defence, Unified Effort, 2015, p. 5. In the Nordic context, military cooperation is generally organised under NORDEFCO (Nordic Defence Cooperation).

56 George Lucas, 'The Coming Storm: Baltic Sea Security Report', Center for European Policy Analysis, Washington DC, Jun. 2015, viewed Aug. 2016, www.cepa.org/sites/default/files/styles/ medium/Baltic\%20Sea\%20Security\%20Report-\%20(1).compressed.pdf.

57 Nina Græger, 'Norges Sikkerhetspolitiske Instrumenter - Utfordringer og Muligheter' (Norway's Security Policy Instruments - Challenges and Possibilities', in Pernille Rieker \& Walter Carlsnaes (eds), Nye Utfordringer for Europeisk Sikkerhetspolitikk. Aktører, Instrumenter og Operasjoner, Oslo: University Printing, 2009, p. 151. 
that the increasingly aggressive Russian foreign policy, since 2014 in particular, marks a new low in NATO-Russia relations. ${ }^{58}$ In his preface to the annual report on NATO activity in 2015, Stoltenberg emphasised restoring predictability to the alliance's relationship with Russia: 'There is no contradiction between increasing the strength of NATO and engaging Russia. Indeed, it is only by being strong that we can develop a cooperative and constructive relationship. ${ }^{59}$ Stoltenberg also stressed this strategy in his inaugural speech in 2014, pointing to his experience with managing bilateral relations with Russia during his 10 years as Norwegian prime minister. ${ }^{60}$

Although Russia is perceived by Norway to be an important and demanding neighbour, Norway remains committed to engaging Russia through its so-called 'dual policy' tradition, which focuses on mutual cooperative interests. For instance, the tradition, which was especially evident from the mid-1970s, instigated closer Norway-USSR cooperation on fisheries management during the Cold War, where the precautionary approach was key ${ }^{61}$ As pointed out by the Norwegian Expert Commission on Norwegian Security and Defence Policy:

There is no contradiction between a distinct policy of firm line-drawing toward Russia and active collaboration. Norway has a long tradition of using this dual policy. As long as Russia's orientation is considered to be interest-based, co-operation will be possible when deemed useful to both parties. Therefore, in difficult periods our policy towards Russia must be based on strategic patience. ${ }^{.2}$

Defence Minister Søreide confirmed Norway's post-Crimea implementation of the dual policy in a March 2015 speech stating that, although Norway suspended bilateral military cooperation with Russia in light of the unilateral annexation of Crimea, it continued day-to-day practical collaboration in coast and border guard activities and search and rescue operations, and cooperation regarding the Incidents at Sea

58 Tuomas Forsberg \& Græme Herd, 'Russia and NATO: From Windows of Opportunities to Closed Doors', Journal of Contemporary European Studies, vol. 23, no. 1, 2015, p. 41.

59 NATO, The Secretary General's Annual Report 2015, 28 Jan. 2016, pp. 7, 10, www.nato.int/cps/ en/natohq/opinions_127331.htm.

60 NATO, 'NATO: A Unique Alliance with a Clear Course', 28 Oct. 2014, www.nato.int/cps/en/ natohq/opinions_114179.htm? selectedLocale=en.

61 Ministry of Defence, Unified Effort, 2015, pp. 71-72; Geir Hønneland, Making Fishery Agreements Work: Post-Agreement Bargaining in The Barents Sea, Cheltenham and Northampton, MA: Edward Elgar, 2013.

62 Ministry of Defence, Unified Effort, 2015. 
Agreement. An open line between the respective countries' national Joint Headquarters and the Northern Fleet is also maintained to avoid misunderstandings or miscalculations. ${ }^{63}$ Reassuring Russia through transparency and open lines has been a main strategy for Norway throughout the Cold War and during later incidents, such as the Russian invasion of Georgia in 2008.

A particularly important civilian arena is the Barents Secretariat, which involves all the countries in the Northern Hemisphere. ${ }^{64}$ In the bilateral relationship, cooperation in civilian policy areas—such as fisheries, minority issues (especially regarding the indigenous Sami people), as well as people-to-people exchanges facilitated by the 2012 visa-free crossings agreement ${ }^{65}$ - have allowed for ongoing communication and collaboration. However, bilateral cooperation in the management of the stream of refugees coming into Norway over the Russian-Norwegian border in the north (at Storskog) has been a mixed experience. ${ }^{66}$

\section{Norway's Stakes in the High North}

As a country with more than 80 per cent of its sea territory and 40 per cent of its land territory located north of the Arctic Circle, the High North is an area of deep interest for Norway. Under the 1920 Svalbard Treaty (Spitsbergen Treaty), Norway's sovereignty over the Svalbard archipelago is formally recognised and supported by the 40 High Contracting countries. The High North is also an area of change occurring on environmental, economic and geopolitical levels. Constant physical fluctuations in the region require close monitoring, the identification and separation of short- and long-term policy approaches and preparedness for potential

63 Søreide, 'Speech by Ine Eriksen Søreide: “One for All, All for One”, 2015.

64 The International Barents Secretariat facilitates multilaterally coordinated activities between the Barents Euro-Arctic Council (BEAC) and the Barents Regional Council. BEAC members include Denmark, Norway, Finland, Iceland, Sweden, Russia and the European Commission. The Norwegian Barents Secretariat focuses on developing Norwegian-Russian relations through funding for bilateral collaborative projects on behalf of the Norwegian Ministry of Foreign Affairs.

65 Heather Yundt \& Catherine Benesch, 'Visa-free Agreement Sign of Strong Border Relationship', Barents Observer, 29 May 2012, barentsobserver.com/en/borders/visa-free-agreement-sign-strongborder-relationship.

66 Alissa De Carbonnel, 'A (Very) Cold War on the Russia-Norway Border', Foreign Policy, 20 Nov. 2015 , foreignpolicy.com/2015/11/20/a-very-cold-war-on-the-russia-norway-border-syrian-refugeesbicycles/; Verdens Gang, 'Russland stanser asyl-returer over Storskog' (Russia Stops Asylum Returns over Storskog), 23 Jan. 2016, www.vg.no/nyheter/innenriks/flyktningkrisen-i-europa/russlandstanser-asyl-returer-over-storskog/a/23601737/. 
crisis situations. ${ }^{67}$ According to the Norwegian Foreign Minister, Børge Brende, the High North constitutes Norway's most important strategic area of responsibility, where Norway promotes a cooperative framework to responding to the changes taking place. ${ }^{68}$ Internationally, Norway has been recognised as an international relations entrepreneur in the Arctic. ${ }^{69}$ This means that Norway has sought to distinguish itself through a role as a 'convenor' in Arctic affairs-bringing together different kinds of actors and interests - and also as a 'bridge builder', especially in assisting other countries in their relationship to and understanding of Russian northern policy. ${ }^{70}$

The extent of Norway's interest in the maritime domain is vast and covers several fields, including fishing, transport, official supply services, deep sea services, drilling seismic oil and gas. Nearly 90 per cent of Norway's export revenues come from sea-based economic activity and resources. As a country that lives off of the sea, Norway's maritime approach is pragmatic: to keep the sea lanes open and to defend the country's rights. This is because its livelihood is dependent on the ocean and its resources. The report from the Expert Commission on Norwegian Security and Defence Policy reiterates the statement from the Ministry of Foreign Affair's white paper on the main guidelines in Norwegian foreign policy, emphasising the role of the international community and international law for Norway's safety:

A robust international framework is important for Norway. Especially for small countries, it is essential that the great powers recognise the importance of common rules of the game and do not threaten the system's existence. In the same way, it is important to maintain international rule of law, institutions, regulations and norms that regulate behaviour and contribute to conflict resolution. The UN should continue to play a central role in this system. As a major maritime state, Norway draws heavily on the global regulations at sea including the UN Convention on the Law of the Sea of 1982, UNCLOS, as constitution of the seas. ${ }^{71}$

67 Katarzyna Zysk \& David W Titley, 'Signal, Noise and Swans in Today's Arctic', The SAIS Review of International Affairs, vol. 35, no. 1, 2015, p. 177.

68 Børge Brende, 'The Arctic: Important for Norway, Important for the World', Harvard International Review, vol. 36, no. 3, 16 Apr. 2015, hir.harvard.edu/the-arctic-important-for-norwayimportant-for-the-world/.

69 Geir Hønneland \& Lars Rowe, Nordområdene - hva nå? (The High North - What Now?), Trondheim: Tapir Academic Press, 2010.

70 Elana Wilson Rowe, 'Arctic Hierarchies? Norway, Status and the High North', Polar Record, vol. 50, no. 1, 2014, pp. 72-79. doi.org/10.1017/S003224741200054X.

71 Ministry of Defence, Unified Effort, 2015, p. 14. 
Engaging the United States in the High North is an area of interest for the Norwegian Government. Cultivating American interest in the region has coincided with efforts to strengthen northern European defence cooperation, as broader and closer cooperation is believed to enhance security of the region on various levels. ${ }^{72}$

\section{High North, Low Tension?}

Whereas the end of the Cold War implied that 'for most other states than Russia the region has remained either marginal or peripheral', the importance of the High North was revitalised in Norway with the Norwegian High North strategy from 2005 onwards. ${ }^{73}$ The significant Russian military build-up on the Kola Peninsula from the mid-2000s also raised concerns about security among Norwegian politicians, diplomats and militaries. In particular, the Russian reopening of old military bases, the increased level of military exercises and, not least, the increase in overflights of Russian bombers and strategic bombers off the coast of Norway sparked a new round of 'New Cold War' rhetoric and media headlines.

Certainly, a more aggressive Russian foreign policy towards Eastern Europe and Ukraine in 2014 in particular has also put the High North, where Russia has 'geo-political and military-strategic interests', back at the top of the Norwegian security and defence policy agenda. ${ }^{74}$ For instance, the main focus of the expert commission was the security challenges that Russia represents in the region, which they describe as 'an arena for geopolitical struggle. ${ }^{75}$ The forward-leaning Russian foreign policy has also gained a lot of attention in Nordic academic environments. ${ }^{76}$ Even after the Ukraine crisis, however, Russia has not been considered as a direct threat to Norway, at least not at present. ${ }^{77}$ As formulated by the head of Norwegian military intelligence, 'Russia has not suddenly

72 Ministry of Defence, Unified Effort, 2015, p. 42.

73 Græger, Norsk Forsvarspolitikk, 2016, pp. 231-32.

74 Ministry of Defence, Unified Effort, 2015, p. 15.

75 Ministry of Defence, Unified Effort, 2015, p. 14.

76 See, for example, Forsberg \& Herd, 'Russia and NATO', 2015; Jo Georg Gade \& Paal Sigurd Hilde, 'Nordområdenes sikkerhetspolitiske betydning for NATO' (The High North's Security Policy Importance for NATO), in Tormod Heier \& Anders Olav Kjølberg (eds), Norge og Russland. Sikkerhetspolitiske utfordringer i nordomradene (Norway and Russia. Security Policy Challenges in the High North), Universitetsforlaget, 2015, pp. 96-109.

77 Ministry of Defence, Unified Effort, 2015, p. 15. 
become a military threat-not in the short term. But, in the long term the picture is more uncertain. ${ }^{78}$ Hence the focus on strengthening the military presence in northern Norway in subsequent defence plans and reports. ${ }^{79}$ Rather than seeing any impending security threats in the region, the Norwegian Ministry of Foreign Affair's Arctic slogan, 'high north, low tension', emphasises the safety aspect of Arctic activity.

All of the peacetime, cooperative military bilateral and multilateral arrangements in the Arctic are between the nation states in the region. For instance, the Ilulissat Declaration of 2008, signed by the five Arctic coastal states, established a common framework for maritime sovereignty in the Arctic Ocean. All signatories have agreed that claims and disputes are to be negotiated between the Arctic coastal states to prevent the escalation of political disagreements into security issues. Norway and Russia, who have had overlapping claims in the Barents Sea for decades, finally managed to conclude negotiations and sign an agreement in 2010.

The role of NATO in the region has been brought up from time to time. NATO is not, however, likely to increase its activity in the Arctic in peacetime and instead encourages the continuation of the cooperation between all of the Arctic states. The defence establishments of the Arctic states promote peacetime confidence-building measures. ${ }^{80}$ There are regular bilateral and multilateral military exercises in the region that include Russia and the individual NATO members among the Arctic states. There are annual informal meetings between military leaders from all of the Arctic states where 'soft security' measures and military support to civilian agencies responsible for safety-related matters are discussed. These matters have become increasingly important with growing levels of human activity in the Arctic Ocean. This emphasis on safety capabilities corresponds with recent efforts under the auspices of the Arctic Council that resulted in a new search and rescue agreement (2011) and an oil-spill preparedness and response agreement (2013).

The requirement for monitoring and safety arrangements depends on the volume and scope of future civilian activities. The Arctic may be a promising area for commercial opportunities. There is a potential

78 Forsvarets Forum, 'Nabovarsel' (Neighbour Warning), 25 Feb. 2015, p. 27.

79 For example, The Strategic Military Review (Fagmilitært råd, FMR), which is the armed forces' own recommendation to the politicians on how the organisation should evolve in the coming years (The Armed Forces, Et Forsvar i Endring, 2015).

80 This refers to the respective national governments' as well as alliance memberships. 
for shorter transcontinental maritime transit though the Northern Sea Route, increasing the profit and value of extraction of onshore and offshore petroleum and mineral resources. Analysts, however, have recently addressed several factors dampening the most optimistic future predictions. Operations in the Arctic environment can be complex, difficult (extremely low temperatures and icing contribute to this) and costly. Profitability of commercial ventures in the Arctic may also be influenced by the dynamics in the market itself and evolving concepts for production and distribution.

The Arctic - where Norway has invested significant political and economic capital — can be seen as a unique arena for the country as a place where Norway meets and interacts with many non-Arctic states. Meeting both Arctic and non-Arctic partners in the High North has been a priority for Norway. For instance, the rapidly growing economies of Asia have expressed a particular interest in the Arctic, which has coincided with Norway's recognition of Asia as an increasingly important arena for Norwegian foreign policy. ${ }^{81}$ Similar to its other Nordic regional partners, Norway has been forthcoming and welcoming of Asian states' Arctic interests, as it encourages broad dialogue on issues affecting the Arctic and competence sharing. Norway welcomes the diverse opinions, complementary expertise and outside-of-the-Arctic thinking that non-Arctic states can provide. Norway has developed especially close bilateral ties on Arctic issues with Singapore, South Korea and Japan. South Korea has prioritised Norway as a cooperation partner in Arctic and regular bilateral interactions between Norway and Singapore and Norway and South Korea have also strengthened collaborative commitments and interest in the region. ${ }^{82}$ Norway proclaimed its support of the Asian states' inclusion in the Arctic Council in early 2013 and continued to play a role in the states' ultimate acceptance and inclusion in the council's ministerial meeting in Kiruna, Sweden, in May 2013. This receptive attitude towards the Asian states can be in part explained by a Norwegian interest in revitalising the Arctic Council. ${ }^{83}$ Given its geographic placement and record in the High North,

81 Ministry of Foreign Affairs, 'Largest Ship of the Norwegian Navy', 2015.

82 Børge Brende, 'Cooperation between Norway and the Republic of Korea in a Changing Arctic Landscape', Norwegian Minister of Foreign Affairs, 2015.

83 Per Erik Solli, Elana Wilson Rowe \& Wrenn Yennie Lindgren, 'Coming into the Cold: Asia's Arctic Interests', Polar Geography, vol. 36, no. 4, 2013, p. 262. doi.org/10.1080/108893 7X.2013.825345. 
Norway can play a significant role as a gatekeeper and facilitator of nonArctic states' interests in the region, which can in turn have positive offshoots in other bilateral, regional and international settings. ${ }^{84}$

\section{Conclusion}

Norway is a country where security and defence are core policy areas and political concerns. It has a well-funded national defence, relatively speaking, but one that is also committed to resolving disputes peacefully, and places great importance on security cooperation and its alliances. Since the first line of defence will often be abroad for small countries like Norway, it recognises the importance of maintaining an international order based on international law and the United Nations. Norway's contributions to NATO operations and important coalitions of the willing, and close bilateral relationship with the United States are also key in this respect. Here, Norway's procurement policy and willingness to contribute to peace operations as well as military enforcement operations around the world has placed it among the preferred allies in the past few years. This is a policy that has not only been conducted for the sake of status and recognition in NATO, but also to signal that Norway is no longer only an importer of security (having anchored its security in NATO's Article 5 since 1949). Given the country's positioning and that its maintenance of international law and order, support of the UN, and enforcement and exercises of sovereignty are major areas of national defence focus, Norway is increasingly also an exporter of security.

The challenges and dynamics inherent in Norway's alliances have led to policy approaches and acquisitions that further commitments beyond Norwegian borders. Norway's participation over the years in expensive procurement programs and ambition not only to participate in but also to host international-and especially NATO_exercises is a testament to the importance of its outward-looking and alliance-anchored security and defence policy. It is also a reflection of raised domestic and allied security concerns related to a more aggressive Russian foreign policy, as well as 'new threats' from terrorism, cyber attacks and 'hybrid warfare'. For a small country located on the outskirts of Europe, the importance of international law and order cannot be overemphasised. This does not,

84 Solli, Rowe \& Yennie Lindgren, 'Coming into the Cold', 2013. 
however, stand in contrast to having a flexible and modern defence, but rather coincides with it. The general concern expressed by several defence ministers over the past decade is the dilemma of facing a situation where a given conflict is too small for NATO, yet too large for Norway to handle alone, or at a point in time where NATO is engaged elsewhere. Consequently, and in response to recent aggressive Russian foreign policy and military build-up, Norway is reallocating and strengthening its military presence in the northern part of the country.

In the High North, Norway is recognised for its entrepreneurial and inclusive approach towards the states and entities involved, as well as its dedication to the maintenance of a safe and predictable Arctic environment and the resolution of disputes in a peaceful, law-abiding manner. Norway's pragmatic dual-policy tradition toward its Russian neighbour has allowed for steady communication and collaboration both in times of war and peace and at various levels of society. Although the long-term outcome of Russia's increasingly strong defence posture is uncertain, at present Russia is not considered to be a direct threat for Norway. With NATO activity in the Arctic unlikely to increase, the continuation of cooperation between the Arctic states through confidence-building measures remains a top foreign policy priority for Norway as it navigates the challenges and dynamics of its modern alliance structures and policies.

NATO, and thus Norway, faces an increasingly complex security environment defined by indiscriminate international terrorism, an unprecedented refugee crisis and a more assertive and unpredictable Russian military posture. With the alliance's primary focus on its core tasks of collective defence, crisis management and cooperative security, Norway's reputation as a defence spender and its extended role as an exporter of security is likely to remain a source of assurance both on bilateral and multilateral levels. 
This text is taken from Global Allies: Comparing US Alliances in the 21st Century, edited by Michael Wesley, published 2017 by ANU Press, The Australian National University, Canberra, Australia. 